\title{
The Manifestations, Causes and Influences of Economic Inequality in the Roman Empire from the 4th to the 5th Centuries
}

\author{
${ }^{1}$ University of Hull, Hull, United Kingdom \\ ${ }^{2}$ Fairfield College Preparatory School \\ *Corresponding author email: b.fan-2018@hull.ac.uk \\ These authors contributed equally.
}

Bofei Fan ${ }^{1, *}$, , Birong Zhang ${ }^{2, \dagger}$

\begin{abstract}
For a long time, economic inequality has been a serious problem that plagued the ruling class, and the Roman Empire, which shaped the Mediterranean civilization, is no exception. However, most historical researches in the past are limited to the macroscopic study of the reasons for the decline of Rome, and in the study of specific reasons, economy is also a rare topic. Therefore, the purpose of this article is to analyze the performance of economic inequality in the Roman Empire and its negative impact on the empire. First of all, this paper gave a detailed discussion on the manifestations of economic inequality in the Roman Empire, and this paper compared the luxury and generosity of honores in the empire with the embarrassment and limitations of the humiliores' life. In the next two main paragraphs, this paper respectively described how economic inequality formed and how it had a negative impact on the empire. Regarding the causes of economic inequality, this paper explained it through morality, law, and a corrupt bureaucracy. Finally, class conflict, ineffective bureaucracy, and excessive dependence on slavery are the core topics of the next paragraph. The article is broken down from the mainstream research directions of the Roman Empire, and innovatively uses economic issues to explain and analyze the decline of the Western Roman Empire in the fourth century.
\end{abstract}

Keywords: Economic inequality, Roman Empire, rule, Imperial decline

\section{INTRODUCTION}

The economic problems of the Roman Empire had already been manifested during the Roman Republic. The Roman Republic during the Republican period plundered a lot of wealth and slaves in its rapid expansion. Most of the wealth and slave resources were allocated to the upper class of the Roman Republic represented by the Senate and Legion Commanders. The resulting prosperous slavery economy brought wealth and resources to Rome, but at the same time it also brought hidden crises to the Roman Republic. The slavery economy made a large number of Roman citizens lose their competitiveness and gradually went bankrupt. This led to the lack of civilian soldiers in the Roman Legion. In order to cope with this crisis, Gracchus hoped to reform the economic structure of the Roman Republic to change the plight of the Roman Legion and maintain the tradition of the civic soldiers in the Roman Republic. Specifically, the reform hoped to distribute the land of the big landlords and nobles to the bankrupt Roman citizens, but the economic reforms harmed the interests of the big estate owners, nobles, veterans, and generals, and ultimately failed. In order to save Rome, Gaius Marius (157 BCE-87 BCE) carried out military reforms that did not touch the vested interests. This resulted in a professional army only loyal to the military commander who paid them instead of the Roman Republic. Military dictators began to emerge after the reform of Gaius Marius and eventually turned the Roman Republic into the Roman Empire. Although Gaius Marius' political and military reforms saved the Roman Republic, the economic problems in the Roman Republic caused a widening gap between the rich and the poor, and the bankruptcy of Roman citizens was never resolved and was brought to the Roman Empire.

The Roman Empire was vast in size and faced numerous governance problems. Economic inequality was one of the important issues, which affected the stability and continued unification of the Roman Empire. In the past, academic circles often focused on macro- 
studies of the Roman Empire's decay, pointing out that the decline of the Roman Empire was a complicated process, but the research on a specific influencing factor from the micro level is still insufficient. Based on this academic background, this research focuses on the analysis at the micro level.

\section{THE MANIFESTATIONS OF ECONOMIC INEQUALITY IN THE ROMAN EMPIRE}

First of all, the economic problems of the Roman Empire are mainly manifested in the extreme inequality of wealth accumulation between the upper-class Romans and ordinary Roman citizens. Another manifestation of the economic problem is the unequal employment opportunities for people of different classes in the Roman Empire. At the same time, the people at the bottom of Rome still lacked opportunities to upgrade their classes. These problems led to the crisis of the Roman Empire in the 4 th and 5 th centuries.

\subsection{Unequal wealth accumulation in the Roman Empire}

The main reason for the collapse of Rome came from the disparity between the rich and the poor in society. With the rapid rise and expansion of the Roman Republic, the land of the new government brought endless wealth, land and slaves to Rome. And these newly acquired resources were not evenly distributed to every Roman citizen, but a large part of it was concentrated in the hands of a small number of Roman nobles, Roman generals and the Senate. Compared with the rich who have gained huge benefits, the poor people have lost their hope in life due to their reduced income from land occupation. They have never been able to gain an advantage in the competition between Roman society and the rich Romans who have run for several generations, and Roman society is more inclined to the side of the rich, since the operation of the empire needs their support, and the governors also come from these royal families. The political resources and the rights of citizens of the rich and the poor are extremely unbalanced. This result is reflected in the chaos of social order and the degradation of Roman life. The rich enjoy infinite wealth and squander a lot of resources.One example is the Roman Empire's rich man Akhno Barbus who promised his 20,000 army to give everyone 4 acres of land. This example can not only show that the Roman Empire's army was fighting for profit at that time, but it can also show the extreme social and economic inequality. For the rich, the reason why he can promise these lands means that these lands are not all his wealth, but only part of it. In the 4-5 centuries AD, Rome and other civilizations in Asia and Europe had trade relations, and countless high-value commodities such as silk, dyes, and spices entered the Roman Empire. The existence of trade means that the Romans are constantly buying these high-value commodities. Obviously, the humiliores of the Roman Empire did not have such purchasing power, so these high-consumption luxury goods became exclusive to the wealthy of the Roman Empire. The poor cannot squander their wealth like the rich, Marcellinus commented on them as "some spend the entire night in wine shops, some lurk in the shade of the awnings of the theatres."[1] Such a society made the originally powerful and passionate Romans become weak and powerless. They had no motivation to fight for the honor of Rome, and lost hope and honor. Such citizens appear vulnerable to powerful barbarians.

\subsection{Inequality of employment opportunities in the Roman Empire}

Another economic problem of the Roman Empire is reflected in the inequality of employment opportunities and the extreme inequality of wealth as a result. Beyond that, the society of the Roman Empire divided Roman citizens into two classes, namely "honestiones" (higherclass citizens) and "humiliores" (lower-class citizens). First of all, the inequality between Roman honestiones and humiliores reflected on job opportunities. For ordinary Roman civilians, the choice of employment opportunities is very limited, the land annexation of the Roman nobles and honestiones and the increase in land taxes caused the humiliores to work all the time and cannot accumulate wealth. Slaves in the Roman Empire were mostly engaged in hard work with low pay in Roman society, while most of the work performed by barbarians in Roman society was to join the army or exist in the form of mercenaries. Most honestiones are born with humorous wealth and land that humiliores cannot obtain even after working for centuries, and most importantly, rights. In Rome's parliament, the humiliores, who accounted for the majority of social groups, could only occupy a small number of seats. Therefore, the opportunity for the individual poor to determine the direction of the empire was even smaller. Unequal job opportunities have led to a huge imbalance in income between general civilians and nobles.

\subsection{Class consolidation in the Roman Empire}

In the Roman Empire, Roman low-class citizens, who accounted for the vast majority of the population, were engaged in jobs that required hard labor, low income, low value, and low status in terms of employment types. The vast majority of people who run the Roman Empire government came from the "Senatus" class. All Roman emperors need the support of the senator to rule the Roman Empire. At this time, the identity background of the senator is very important. Most empires are the most important. All official positions are occupied by the veteran class. The members of the Senate appointed by the Roman emperor have a high status, but they need a lot of money as support, as Leonhard Schmitz 
commented, "only the wealthiest persons of the empire, no matter to what part of it they belonged, that could aspire to the dignity of senator $\sim$ a list of them, together with an account of their property" [2]. The seats generally occupied by the powerful and wealthy senators are the provincial government, the commander of the Roman legion, and the Senate. The emperor of the Roman Empire needed the support of the elder class, and the emperor obtained their support by giving them important jobs. Under such a system, the remaining official positions became extremely scarce, and such a scarce position had little to do with civilians and slaves who accounted for $97 \%$ of the Roman Empire's population.

\section{REASONS FOR ECONOMIC INEQUALITY IN THE ROMAN EMPIRE}

If the growing economic inequality between Roman societies is a manifestation, then what is the underlying cause of this situation is worthy of in-depth study. After studying various primary sources, this essay preliminarily summarizes the three essential causes of economic inequality in Roman society.

\subsection{The collapse of the moral system}

The first one is the collapse of the moral system in Roman, in the early days, the economic system of the empire was self-consistent, and it was a small country dominated by a natural economy. "The Western Roman Empire economy was predominantly agricultural and labour intensive."[3] said historian Malcolm Levitt. Although the climate problem will affect Rome's income and food supply to a certain extent, it does not affect their morality. The Roman Empire has a fairly complete legal and democratic system. Instead, when the borders of the empire began to expand on a large scale, silks, spices, precious metals and other luxury goods from the East flooded into the Roman market and began to corrupt the Roman moral system. During this period, many farmers took the initiative to abandon their land in the countryside and came to the city to live on the government's regular relief funds, and they usually spent these relief funds in wineshop or gambling [4]. This not only increased the burden on the empire, but also reduced the number of experienced laborers in the countryside, which indirectly led to the backwardness of the Roman Empire's agricultural development. And this situation is not based on external influence, on the contrary, it is caused by changes in the ideological level. In summary, the worship of money makes it impossible to maintain high moral standards. Whether it is the extravagance of the rich or the time spent by the poor on gambling and chariot racing [4], these are the consequences of the malformation of mainstream social values (the excessive worship of money).

\subsection{Unequal laws}

The second essential cause of economic inequality was the inequality of laws in Roman society. The rich, landlords and politicians had inherently more legitimate rights and interests than the poor, peasants and slaves. Like brutal and bloody gladiatorial matches, slaves and captive barbarians are often fed to beasts. This kind of disregard for life was not until the late third century began to be banned by the emperors (mainly Valentinian I and Theodosius I) re-examining its cruelty and necessity. Meanwhile, high tax is a heavy burden for most farmers. If they cannot pay taxes on time, they can only be forced to sell their land or children to ensure that they will not be imprisoned and become slaves.[4] This is also mentioned in Levitt's article. The treatment of slaves in the empire was even worse. They were not even considered humans. According to the Roman historian Keith Bradley's explanation of the situation of slaves: "An injury suffered by a slave was to be reckoned as only half the value of an identical injury to a free person."[5] The rich (landlords and Patrician in the city) accounted for only 3\% [6] of Roman society, but they had many privileges, such as having more seats in the parliament and holding high political offices. Furthermore, rich people in government will use all means to guarantee their own interests, such as passing targeted laws. This kind of vicious cycle results in the lower class having no ability to change the status quo at all, even if they realize that economic inequality is huge.

\subsection{Corrupt bureaucracy}

The last essential reason is that corrupt bureaucracy leads to ineffective supervision of the rich. Because of its scale, the operation of the Roman Empire was highly dependent on a complete and complex bureaucratic system. In the late 4th century, a considerable proportion of public officials in Roman towns had used their rights to participate in various degrees of corruption. By 386AD, the empire even legalized officials' rake-offs from public utilities [7]. There has been a lot of debate about this view in academic circles. For example, British historian Peter Heather explained in his book: "Much of what we might term 'corruption' in the Roman system merely reflects the normal relationship between power and profit."[8] It is undeniable that the proportion of the upper class in the Roman government is quite large. As I said before, the aristocracy will often use power for personal gain. To some extent, Patrician is another ruling class in Roman society besides the emperor. "Senators had to own property worth at least 250,000 times a laborer's daily wage"[9] American sociologist Robert J. Antonio in his book brilliantly summarized the connection between Roman politics and economy. Under this premise, corruption has almost become the only choice for Roman officials. Whether these officials are sponsored by the 
aristocracy or are Patrician themselves, it seems reasonable to seek benefits for their own class.

\section{THE IMPACT OF ECONOMIC INEQUALITY ON THE DECAY OF THE ROMAN EMPIRE}

Rome was not built in a day, and its decline is also a complicated and lengthy process. In fact, the political heritage and cultural wealth left by the empire have profoundly affected the entire Western society until the present. This essay firmly believes that economic inequality is one of the important reasons for the decline of the Western Roman Empire. In the following paragraphs, this essay will summarize a series of evidence to prove how economic inequality in imperial society caused irreparable harm to Rome.

\subsection{Serious class contradiction}

Until the fall of Rome in the fifth century due to multiple invasions by barbarians such as Gothic and Vandal, the economic problems of the empire had not yet been solved. First of all, we need to clarify a prerequisite, that is, Rome is indeed in an economic crisis, whether it is the expansion of the army or the division of the Eastern and Western Roman Empire, directly or indirectly increased the empire's financial burden. The most intuitive negative impact of economic problems is reflected in the imperial society. Since the fourth century, the social problems of the Western Roman Empire have become more and more serious, and the conflicts between various classes are particularly obvious. As mentioned in the previous paragraph, the class basically solidified in the late empire, that is, the rich got richer and richer, and the poor could not escape the destiny of poverty in their lifetime. For example, according to the Price Edict of Diocletian published in the early fourth century (301AD), the average daily salary of a farm labourer in Rome was 25 denarii [10]. And some non-manual labor occupations, such as Elementary teacher, their salary is 50 denarii monthly for each pupil [10]. However, the prices of commodities on the market are much higher than their income. For example, special silk or spices from the East, the price of White unprocessed silk is 12,000 denarii per pound [10], and the price of purple is even more exaggerated, at 150,000 denarii per pound [10]. This has caused these items that can significantly improve the quality of life to become the privilege of the rich.

\subsection{Incompetent bureaucracy}

The second negative impact is the destruction of the empire's bureaucracy. This and the argument in the previous paragraph are actually complementary way. Because of the incompetence and inefficiency of the imperial bureaucracy, the use of power for personal gain and corruption by the rich cannot be effectively curbed.
Conversely, the corrupt and incompetent bureaucracy directly reduced the possibility of economic inequality in the empire being completely resolved. The original intention of the bureaucracy is to help the empire maintain a large territory while having a certain ability to manage specific affairs. In the late fourth century, under the background of economic inequality, the bureaucracy of the empire was almost completely controlled by the nobles, who ensured their stability by purchasing a large number of votes from the poor. The poor are more likely to sell their votes just by seeing their immediate benefits. They do not know that these vested interests who manipulate elections will re-exploit money from the poor into their own pockets in disguise through ostensibly reasonable means such as tax increases. From the cruel description of the bureaucratic system of the late Roman Empire by the Greek historian Marcellinus in his book "History", it is easy to know that under the unfair judicial system in Rome, many senators, nobles or civilians "are accused" at of poisoning, fornication, and adultery, and executed."[11] With the failure of the bureaucracy, the empire not only lost the support of a large number of citizens, but it also became difficult to maintain the existing territory.

\subsection{Excessive dependence on slavery}

The last negative impact caused by economic inequality is the empire's excessive dependence on slavery. The slaves of the early Roman Empire usually consisted of barbarians captured in battle, and then allowed this specific ethnic group to naturally multiply. And because of the high taxes caused by economic inequality, many farmers are forced to become slaves to ensure that they can get food and shelter. The disadvantages of slavery are obvious. Whether in terms of human rights or economics, the harm of early slavery to Roman society was covered by the dividends brought about by continuous military victory and territorial expansion, but with the military defeat of the barbarians, The harm of slavery began to become prominent. Due to the high dependence on slavery, the technological development of the empire was extremely slow, and a large number of slaves without any consumption ability could not continue to rely on export goods to promote the economic growth of the empire, forming a vicious circle. The more serious problem is that some slaves could not bear the high-intensity labor and the exploitation of their productivity by the nobles, and they began to riot. They systematically attacked landlords, destroyed farm tools, and killed and burned livestock. As a result, agricultural development in the provinces of western Rome was almost stagnated.

\section{CONCLUSION}

In order to explore the reasons for the decline of the Roman Empire (the economic problems of the Roman 
Empire) at the micro level, this paper introduces the manifestations of social and economic inequality in the Roman Empire, and then analyzes and summarizes the social atmosphere of the Roman Empire in the 4th and 5 th centuries. The third part of the article analyzes the impact of economic inequality on the decline of the Roman Empire.

The research direction of this paper is different from the general research on the decline of the Roman Empire in academic circles, and its innovation is manifested as a unique research direction. The value of this research article is embodied in the analysis of the micro-level economic and social problems of the Roman Empire, exploring and analyzing the economic problems of the Roman Empire at the micro-level and the impact of these problems on the decline of the empire. The research in this article can provide thought support for the future research on the decline of the Roman Empire. Since this research only explores the causes and manifestations of economic problems within the Roman Empire, it can be combined with other civilizations in the world during the same period in future research about the study of the economic structure of the world, and the impact of the economic and social structures of other civilizations in the world on the Roman Empire.

\section{REFERENCES}

[1] Marcellinus A. Histories, Book 31, pp. 499. https://penelope.uchicago.edu/Thayer/E/.

Roman/Texts/Ammian/home.html.

[2]. Zosim. II. Cod. Theod., Symmach. Epist. IV. pp.61. .https://penelope.uchicago.edu/Thayer/L/. Roman/Texts/Ammian.html

[3] Levitt M. "The Western Roman Empire." Why Did Ancient States Collapse?: The Dysfunctional State, Archaeopress, 2019, pp. 25.

[4] Marcellinus A. Histories, Book 14, pp.51-53, http://penelope.uchicago.edu/Thayer/E/Roman/Tex ts/Ammian/home.html.

[5] Bradley K R. "Roman Slavery and Roman Law". Historical Reflections/Réflexions Historiques, 15(3), 1988, pp.492.

[6] Heather P. The Fall of Rome. http://www.bbc.co.uk/history/ancient/romans/fallof rome_article_01.shtml

[7] MacMullen R. Corruption and the Decline of Rome.New Haven, London: Yale University Press, 1988, pp. 151.

[8] Heather P. The Fall of the Roman Empire: A New History of Rome and the Barbarians. New York: Oxford University Press, 2005, pp.100.
[9] Antonio R J. "The Contradiction of Domination and Production in Bureaucracy: The Contribution of Organizational Efficiency to the Decline of the Roman Empire." American Sociological Review, 44(6), 1979, pp. 900.

[10] Kropff A. An English translation of the Edict on Maximum Prices, also known as the Price Edict of Diocletian. (Edictum de pretiis rerum venalium), https://www.academia.edu/23644199/New_English _translation_of_the_Price_Edict_of_Diocletianu

[11] Marcellinus A. Histories, Book 28, pp.87, http://penelope.uchicago.edu/Thayer/E/Roman/Tex ts/Ammian/home.html. 